\title{
Douche Dosage Form
}

National Cancer Institute

\section{Source}

National Cancer Institute. Douche Dosage Form. NCI Thesaurus. Code C42679.

A substance intended for use as a vaginal irrig ant. 